\title{
Fractionation of Fe, Zn, Cu and Health Risk Appraisement in two Terrestrial and Aquatic Snails Commonly Consumed in Nigeria
}

\author{
DOUYE PARKINSON MARKMANUEL ${ }^{1 *}$ and EREPAMOWEI YOUNG ${ }^{1}$ \\ Department of Chemical Sciences, Faculty of Science, Niger Delta University, Wilberforce Island, \\ P.M.B 071, Yenagoa, Bayelsa State, Nigeria. \\ *Corresponding author E-mail: douyemarkmanuel@yahoo.com, douyemarkmanuel@gmail.com
}

http://dx.doi.org/10.13005/ojc/360415

(Received: June 23, 2020; Accepted: July 30, 2020)

\begin{abstract}
This study consist of chemical fractionation of $\mathrm{Fe}, \mathrm{Cu}$ and $\mathrm{Zn}$ in two commonly consumed terrestrial and aquatic snails, and appraised the risk associated via consumption. The concentrations of the metals in each fraction were analyzed using Flame Atomic Absorption Spectrometer. Results showed that, $\mathrm{Fe}$ accumulated higher than $\mathrm{Cu}$ and $\mathrm{Zn}$ in all the snails. Fe levels were highest in the residual fraction and the values were higher than standard maximum limits of M.A.F.F. and W.H.O./F.A.O. except I.A.E.A., while $\mathrm{Cu}$ and $\mathrm{Zn}$ levels were below their limits. Risk appraisement study showed that, Fe was a major risk contributor to the H.I. values, accounting over $70 \%$. The study also revealed that, a daily consumption of $0.025 \mathrm{mg} \mathrm{kg}^{-1}$ - bw day ${ }^{-1}$ of $\mathrm{Fe}, \mathrm{Cu}$ and $\mathrm{Zn}$ via these snails will not pose non-carcinogenic risk to consumers for now but, in light of metal toxicity and its bio-accumulative nature, moderate intake of these snails is advisable.
\end{abstract}

Keywords: Fractionation, Heavy Metals, Risk Appraisement, Terrestrial and Aquatic Snails.

\section{INTRODUCTION}

Fractionation is a separation process in which analyte(s) of a given matrix are partitioned into smaller fraction according to size, density, solubility, bonding or reactivity ${ }^{1}$. Basically, fractionation studies focus on the chemical nature of the species under investigation which include solubility, affinity, charge, hydrophobicity/hydrophilic, and in some cases, physical separation such as filtration and sizeexclusion chromatography may also be involved ${ }^{2}$.

Fractionation can also be viewed as additional methods of speciation analysis. For instance, a fractionation of Copper in an unpolluted ecosystem can be investigated to ascertain the different chemical forms of copper which could be organic or inorganic. Also, discrete analysis may also be carried out to determine the inorganic fraction by identifying individual inorganic species of $\mathrm{Cu}$ in a given sample. However, there are two basic approaches in fractionation techniques. These include, "physical fractionation where the separation of the analyte is based on particle size and density ${ }^{3}$ and "chemical fractionation which focused on selective dissolution of the analyte(s) or contaminants in different reagents ${ }^{2}$. Krauss et al., ${ }^{3}$ studied the distribution of heavy metals in different

This is an Open Access article licensed under a Creative Commons license: Attribution 4.0 International (CC- BY). Published by Oriental Scientific Publishing Company @ 2018

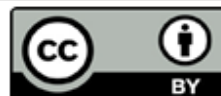


particle sizes and density fraction of municipal refuse. Their study revealed that, the fine dense fractions had the highest heavy metal content and coarse light fraction contained the least amount of each heavy metal.

According to Okoro et al., ${ }^{2}$ the environmental fate of metals, that is, their toxicity, bioavailability, mobility and rate of contamination in an organism are correlated with different forms or species of the metal than total concentration because, the former gives further information about the fundamental reaction that governs the behaviour of metals. Therefore, chemical fractionation schemes for partitioning heavy metals via sequential extraction procedures have been found to be the most effective method in evaluating individual fraction of heavy metals ${ }^{4}$. Again, these are based on three (3) to six (6) fractions or more, most of which are derived and modified from Tessier's scheme ${ }^{5-6}$. Basically, in chemical fractionation two different approaches are available; these include single extraction using one reagent only or sequential extraction using different chemical reagents ${ }^{7}$. However, the later approach was employed in this study.

Sequential extraction procedures (SEP) are functionally valued methods of fractionation which is commonly employed to assess metal mobility, bioavailability and toxicity in an environmental matrix ${ }^{8-10}$. The principal advantages of sequential extraction over single extraction procedure are as follows;

- Sequential extraction procedure improves the phased specificity.

- It provides vital knowledge for risk evaluation because, metal concentrations obtained using different chemical reagents can be determined.

- $\quad$ Also, it provides information on the diverse bonding strength of metals in liquid and solid phases and their potential reactivity under different ecological condition ${ }^{11}$.

The fundamental principle of sequential extraction procedures is based on the potency of the reagent or extractant to successfully dissolve the analyte(s) into its component form in a sequential order, liberating the analyte(s) within the matrix or sample without affecting other components ${ }^{12}$.
Generally, fractionation and speciation of heavy metals on environmental samples, provide insight on the elemental bioavailability, mobility and toxicity and this may present a better degree of heavy metal pollution compare to total metal concentration since, heavy metals exist in different chemical forms and only a fraction can be remobilized easily, the later provides no insight to elemental bioavailability and mobility ${ }^{13}$.

Terrestrial and aquatic snails are nonconventional important wildlife protein source. However, recent studies have shown that the consumption of snails has been on the increase due to its nutritional values, such as; high protein content, minerals and vitamins, which are required for normal tissue development and maintenance ${ }^{14}$. Snails are also reported to have low lipid content, saturated fatty acids and low cholesterol content, which help to prevent diabetes and heart related diseases ${ }^{15-16}$.

In Nigeria, edible snails are part of culinary delicacies and the demand has been on the increase. Snail (especially land snails) farming in cities is now gaining importance ${ }^{17}$. While in the rural communities, these snails are collected from the forest and water bodies ${ }^{18}$, and traditionally, they form a single item of animal protein in the diet of consumers ${ }^{19}$. The snails used in this study include; Achatina achatina, Limicolaria flammea commonly referred to as the giant land and garden snails, and Pachymeria aurita, Tympanotous fuscatus commonly known as marine periwinkles.

Several studies had revealed the importance of snails (gastropods) as a good bioindicator for monitoring heavy metals pollution in terrestrial and aquatic environments due to their mode of feeding ${ }^{15,20-22}$. Since these snails are filterfeeding organisms, the possibility of accumulating chemical elements or toxicants in their tissues is inevitable. Therefore, consumption of snails may be an important route for human exposure to toxic metals and this may pose risk to human health. In view of this, it is eminent to investigate the fractionation (chemical forms) of $\mathrm{Fe}, \mathrm{Zn}, \mathrm{Cu}$ in two terrestrial (Achatina achatina, Limicolaria flammea) and aquatic snails (Pachymeria aurita, Tympanotous fuscatus) and assess the health risks related via consumption of snails. 


\section{MATERIAL AND METHODS}

\section{Materials and Reagents}

Terrestrial snails (Achatina achatina, Limicolaria flammea), aquatic snails (Pachymeria aurita, Tympanotous fuscatus), $250 \mathrm{~mL}$ conical flask, Weighing balance, $250 \mathrm{~mL}$ beakers, funnel, spatula, stirring rod, Whatman filter paper (No. 541), aluminium foil, measuring cylinder, hot plate, Flame Atomic Absorption Spectrophotometer (GBC avanta 2.02 model), distilled water, hexane, methanol/DCM (8:2), aqua regia (3: $\mathrm{V} / \mathrm{V}$ Conc. $\mathrm{HCl} / \mathrm{HNO}_{3}$ ) and $\mathrm{HClO}_{4}$.

\section{Sampling and Sample Preparation}

Two commonly consumed terrestrial snail species (Achatina achatina, Limicolaria flammea) and aquatic snails (Pachymeria aurita, Tympanotous fuscatus) were bought from local farmers in Yenagoa main market, Bayelsa State, Nigeria. Immediately, after collection, the snails were rinsed with cold water, wrapped in bags, labelled accordingly. Upon preparation the snails' shells were cracked open to obtain the whole soft tissues (edible parts). The soft tissues were washed thoroughly with distilled water, oven dried at $105^{\circ} \mathrm{C}$ and ground to fine powder.

\section{Fractionation Analysis}

Fractionation analyses were determined using three-stage sequential chemical extraction procedures ${ }^{4}$. The chemical extractants employed in this study were, water, hexane and methanol/ dichloromethane (8:2), and these gave rise to;

- Water soluble fraction, WSF

- Non-polar (hexane) fraction (NHF)

- Polar (methanol) fraction, PMF

\section{Determination of Water Soluble Fraction}

Approximately, $1.0 \mathrm{~g}$ of each snail biomass was weighed into extraction bottles and $15 \mathrm{~mL}$ of distilled water was added. The mixtures were placed on an electrical shaker for twenty four (24) hours. Thereafter, the mixtures were removed, filtered and the water soluble fractions (WSF) were obtained. Then, the residues were dried at room temperature for two days.

\section{Determination of Non-Polar/or Hexane Fraction}

The dried residues of the WSF were put into extraction bottles, and $10 \mathrm{~mL}$ of hexane was added. All mixtures were placed on electrical shaker for twenty-four (24) hours. The extraction bottles were removed, then, the mixtures were filtered and the Non-polar or hexane fractions (NHF) were obtained, and the residues were dried at room temperature for two days.

\section{Determination of Polar/or Methanol Fraction (PMF)}

$10 \mathrm{~mL}$ of methanol/dichloromethane (8:2) was added to the dried residues of NHF and placed on an electrical shaker for twenty four (24) hours. Thereafter, the mixtures were removed, filtered and methanol/or polar extracts were obtained. Again, the residues were dried at room temperature for two days.

\section{Digestion of Residual Fraction, (RSF)}

$10 \mathrm{~mL}$ of conc. $\mathrm{HCl} / \mathrm{HNO}_{3}$ was added into $250 \mathrm{~mL}$ beakers containing the dried residues of the polar (methanol) fractions (PMF), thereafter 1 $\mathrm{ml}$ of $\mathrm{HClO}_{4}$ was also added. The mixtures were heated on a hot plate in a fume chamber until all the residues completely went into solution ${ }^{23}$. Then, the digests were allowed to cool, diluted to $25 \mathrm{~mL}$ with distilled water, stirred and filtered to obtain the residual fractions (RSF).

\section{Analysis of $\mathrm{Fe}, \mathrm{Cu}, \mathrm{Zn}$ in Each Fraction}

The concentrations of $\mathrm{Fe}, \mathrm{Cu} ; \mathrm{Zn}$ in each fraction were analysed by Flame Atomic Absorption Spectrophotometers, FAAS (GBC Avant aver 2.02 design).

\section{Quality Assurance/Control}

Preparation of reagent blanks, triplicate samples, a certified reference material solutions provided by NRC, Canada and triplicate metals determination were some of the parameters used to check the quality assurance/control in this study. Also, Pearson correlation coefficient $>0.98$ was considered acceptable. Again, percentage recoveries of the metals, $\mathrm{Fe}, \mathrm{Cu}, \mathrm{Ze}$ ranged from $90.67 \%-99.60 \%$, which indicates accuracy of result as well as good precision.

\section{Health Risk Appraisement}

Health risk appraisements are the fastest growing methods in assessing the pollution standards of metals in the environment and its biota ${ }^{23,24-26}$, because they provide information emanating from metal presence in the environment, biota and other food products. Health risk appraisal methods may be subdivided into two; non-carcinogenic risk (THQ of the 
individual metal and the combine hazard indices, $\mathrm{HI}$ of all the metals in a given matrix) and carcinogenic risk $(\mathrm{TR})^{23}$ as proposed by the United State Environmental Protection Agency (U.S.E.P.A.) ${ }^{27-29}$. However, this study investigated only the non-carcinogenic risk of $\mathrm{Fe}, \mathrm{Cu}, \mathrm{Zn}$ in land and marine snail's fractions. The methods employed to determine the non-carcinogenic risk of these metals were;

- $\quad$ The Estimated Dietary Intake (EDI) expressed mathematically as follows; EDI (mg kg-1 bw-day $\left.^{-1}\right)=\frac{M I X M C_{(S)}}{B W a}$

EDI: This is the maximum amount of estimated dietary intake of a contaminant or toxicant in which a person can be exposed to per day over a life time without an unacceptable risk of health effects.

- $\quad$ The Target Hazard Quotient (THQ i.e the hazard quotient of the individual metals).

$=\frac{E F \times E D \times M I_{(s) X M C_{S}}}{R F d \times B W_{a} \times A T n} \quad 10^{-3}$

THQ defines the relative magnitudes between exposure to a pollutant and the average reference dose of the pollutant.

- $\quad$ Hazard Index $(\mathrm{HI})$. That is the combined or total sum of THQ effects of the individual metal in the snails. It is expressed as;

$H I=T H Q_{F e}+T H Q_{C u}+T H Q_{Z n}$

$\mathrm{HI}$ : The interpretation of $\mathrm{HI}$ values is binary; $\mathrm{HI}$ is either $>1$ or $<\mathrm{I}$. When $\mathrm{HI}$ is $<\mathrm{I}$, the exposed population is at safe limits but, when $\mathrm{HI}>\mathrm{I}$, it indicates reason for concern because the exposed population is at risk ${ }^{28}$.

Table 2: Levels of Fe, Cu, Zn (mg kg-1 dry wt) in the WSF, NHF, PMF, and RSF of terrestrial and aquatic snails in comparison to standard limits of MAFF, FAO/WHO and IAEA

\begin{tabular}{|c|c|c|c|c|}
\hline Fractions & Snails & Iron $(\mathrm{Fe})$ & Copper (Cu) & Zinc $(Z n)$ \\
\hline \multirow[t]{4}{*}{ Water soluble fraction (WFS) } & Achatina achatina & $294.03 \pm 18.85$ & $1.75 \pm 0.07$ & $7.55 \pm 2.22$ \\
\hline & Limicolaria flammea & $212.30 \pm 56.16$ & $1.75 \pm 0.70$ & $20.55 \pm 1.75$ \\
\hline & Pachymeria aurita & $33.35 \pm 32.80$ & $8.60 \pm 0.50$ & $3.50 \pm 0.82$ \\
\hline & Tympanotous fuscatus & $21.00 \pm 4.24$ & $5.40 \pm 0.68$ & $4.15 \pm 0.62$ \\
\hline \multirow[t]{4}{*}{ Non-Polar (Hexane) fraction (NHF) } & Achatina achatina & $12.92 \pm 0.06$ & $3.27 \pm 210$ & $26.20 \pm 2.10$ \\
\hline & Limicolaria flammea & $34.23 \pm 0.51$ & $5.63 \pm 0.75$ & $28.50 \pm 0.41$ \\
\hline & Pachymeria aurita & $29.60 \pm 4.52$ & $2.80 \pm 1.44$ & $26.40 \pm 0.99$ \\
\hline & Tympanotous fuscatus & $34.80 \pm 2.41$ & $8.30 \pm 0.13$ & $27.80 \pm 1.80$ \\
\hline \multirow[t]{4}{*}{ Polar (methanol) fraction (PMF) } & Achatina achtina & $6.23 \pm 3.45$ & $0.63 \pm 0.24$ & $13.73 \pm 63$ \\
\hline & Limicolaria flammea & $12.30 \pm 3.91$ & $0.70 \pm 0.40$ & $14.20 \pm 0.90$ \\
\hline & Pachymeria aurita & $11.00 \pm 6.30$ & $0.97 \pm 0.42$ & $14.40 \pm 0.90$ \\
\hline & Tympanotous fuscatus & $10.50 \pm 5.60$ & $0.93 \pm 0.25$ & $14.20 \pm 1.03$ \\
\hline \multirow[t]{4}{*}{ Residual fraction (RSF) } & Achatina achatina & $2036.70 \pm 0.91$ & $26.25 \pm 0.65$ & $26.42 \pm 0.31$ \\
\hline & Limicolaria flammea & $635.27 \pm 0.34$ & $13.53 \pm 0.98$ & $63.70 \pm 0.12$ \\
\hline & Pachymeria aurita & $1078.68 \pm 0.38$ & $43.38 \pm 2.43$ & $14.30 \pm 1.50$ \\
\hline & Tympanotous fuscatus & $1767.02 \pm 1.43$ & $16.85 \pm 0.25$ & $25.33 \pm 0.12$ \\
\hline MAFF $^{32}$ & & - & 20 & 50 \\
\hline $\mathrm{FAO} / \mathrm{WHO}^{33}$ & & 2 & 30 & 75 \\
\hline $\mathrm{IAEA}^{34}$ & & 146 & 3.28 & 67.1 \\
\hline
\end{tabular}

Table 1: summary of risk assessment parameters

\begin{tabular}{|c|c|c|c|}
\hline Symbo & Description & Unit & Value(s) \\
\hline $\mathrm{Ml}_{\mathrm{s}}$ & $\begin{array}{l}\text { Mass of the } \\
\text { snail ingested }\end{array}$ & $\mathrm{Kg}$ day $^{-1}$ & 0.025 \\
\hline $\mathrm{MC}_{\mathrm{s}}$ & $\begin{array}{l}\text { Metal Concentration } \\
\text { in the snails }\end{array}$ & $\mathrm{mg} \mathrm{kg}^{-1}$ & $\begin{array}{l}\text { Presented } \\
\text { in Table } 2\end{array}$ \\
\hline $\mathrm{EF}$ & Exposure frequency & days year ${ }^{-1}$ & 365 \\
\hline WD & Exposure duration & Years & 51.86 \\
\hline $\mathrm{BW}_{\mathrm{a}}$ & Body weight adult & $\mathrm{Kg}$ & 60 \\
\hline $\operatorname{RfD}^{\mathrm{a}}$ & Oral Reference Dose & $\mathrm{mg} \mathrm{kg}^{-1}$-bw day ${ }^{-1}$ & $\begin{array}{c}\mathrm{Fe}=0.7 \\
\mathrm{Cu}=0.04 \\
\mathrm{Zn}=0.3\end{array}$ \\
\hline$A T_{n}$ & $\begin{array}{l}\text { Average Time for } \\
\text { non-carcinogens }\end{array}$ & Days & $\begin{array}{c}E D X E F=365 X 51 . \\
86=18928.9\end{array}$ \\
\hline $10^{-3}$ & $\begin{array}{l}\text { Is the unit conversion } \\
\text { factor }\end{array}$ & - & - \\
\hline
\end{tabular}

The ingestion rate is derived from the annual consumption rate of fish, shellfish and meat products in towns and cities of Nigeria as proposed by F.A.O. which is averaged $9.0 \mathrm{~kg}$ and is equivalent to $0.025 \mathrm{~kg}$ per day ${ }^{30}$. Other parameters were derived from similar studies in Nigeria and U.S.E.P.A. risk based assessment Table. ${ }^{23,26,28,31}$.

\section{RESULT AND DISCUSSION}

\section{$\mathrm{Fe}, \mathrm{Cu}, \mathrm{Zn}$ levels in each fraction of the snails}

The mean levels of $\mathrm{Fe}, \mathrm{Cu}, \mathrm{Zn}$ in the snails in various fractions and their comparison to standard limits set by regulatory bodies are presented in Table metals concentrations were unevenly distributed among the snail species studied which depend on the availability of each metal in the snail's environment. Generally, it was observed that Fe accumulated higher concentrations in most of the snail fraction especially the residual fraction. 2 and Fig. 1, 2 and 3 . The result showed that the 


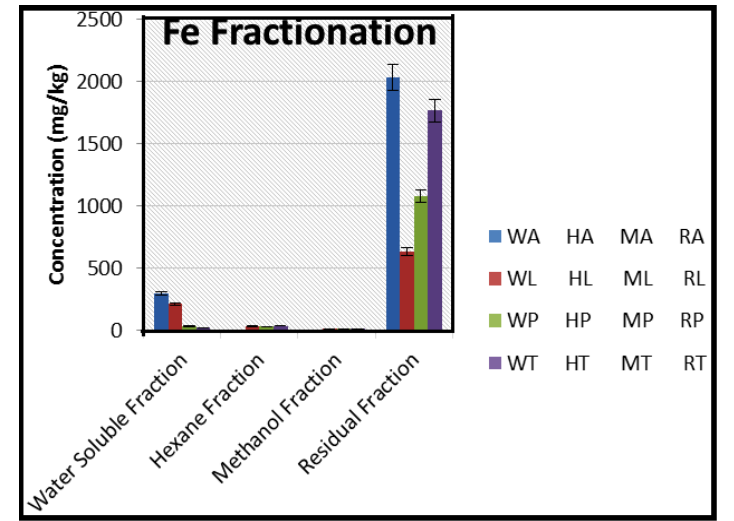

Fig. 1. Mean Concentrations of Iron in the Snail Samples (Achatina achatina, Limicolaria flammea, Pachymeria aurita and Tympanotous fuscatus) of different fractions

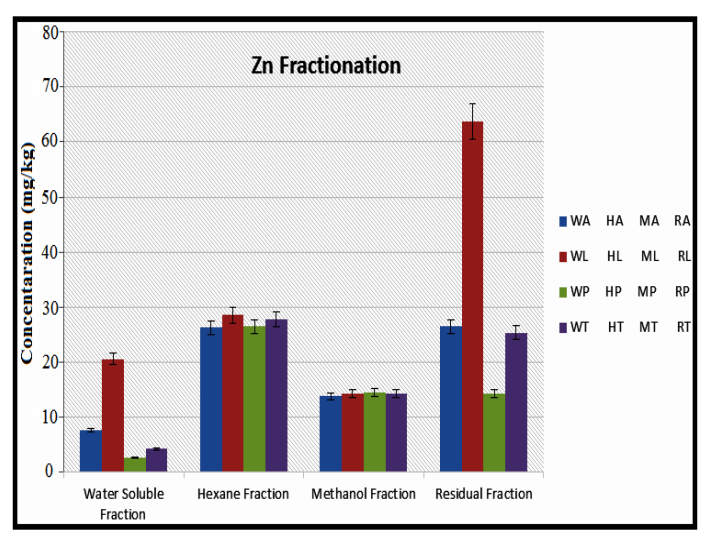

Fig. 2. Mean Concentrations of Copper in the Snail Samples (Achatina achatina, Limicolaria flammea, Pachymeria aurita and Tympanotous fuscatus) of different fractions

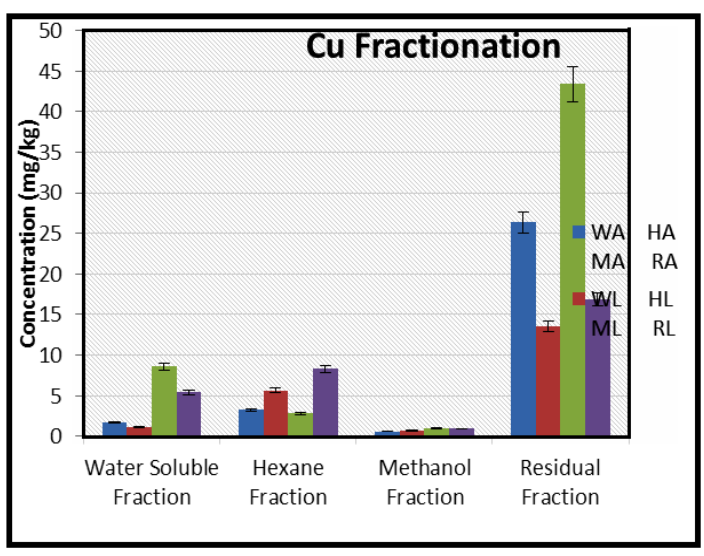

Fig. 3. Mean Concentrations of Zinc, $\mathrm{Zn}$ in the Snail Samples (Achatina achatina, Limicolaria flammea, Pachymeria aurita and Tympanotous fuscatus) of the different fractions

- WA, HA, MA, RA = water soluble, Hexane, Methanol and Residual fractions of Achatina achatina.
- $\mathbf{W L}, \mathbf{H L}, \mathbf{M L} \& \mathbf{R L}=$ water soluble, Hexane, Methanol and residual fractions of Limicolaria flammea.

- $\quad$ WP, HP, MP, \& RP = water soluble, Hexane Methanol and residual fractions of Pachymeria aurita.

- $\quad$ WT, HT, MT, RT = Water soluble, Hexane Methanol and residual fractions of Tympanotous fuscatus respectively.

\section{Concentration of Iron (Fe)}

The findings in Table 2 revealed that, Fe concentrations in the different fractions (WSF, NHF, PMF and RSF) of the snails were unevenly distributed depending on the snail's species. This is attributed to the bioavailability of Fe for uptake by these snails because bioavailability depends on the amount of Fe readily available for uptake by these organisms in their environment. It was observed that, the residual fraction (RSF) in all the snail species recorded the highest values which ranged from $635.27 \mathrm{mg} \mathrm{kg}^{-1}$ - $2036.70 \mathrm{mg} \mathrm{kg}^{-1}$ compared to other fractions. This implies that, most of the Fe species (especially complexes) were locked up during the extraction process and these bonds were broken during strong acid digestion and the metals were released, while the comparable amount found in the water soluble fraction for each of the snail species may be attributed to highly dissolved water soluble species of $\mathrm{Fe}$ in these organism.

Generally, the concentrations of $\mathrm{Fe}$ in all the fractions were more than the recommended standard values of M.A.F.F. ${ }^{32}$, F.A.O./W.H.O. ${ }^{33}$, except I.A.E.A. ${ }^{34}$. Also, Fe levels in these snails are higher than the values reported by lbe et al., ${ }^{35}$ which were $0.950 \mathrm{mg} \mathrm{kg}^{-1}$ and $2.061 \mathrm{mg} \mathrm{kg}^{-1}$ in catfish and tilapia. However, the Fe levels in some fractions (especially the polar (PMF) and non-polar (NHF) are lower than the range values of $198.73-457.11 \mathrm{mg} \mathrm{kg}^{-1}$ reported by Olowoyo, ${ }^{36}$ in periwinkles except in the residual fraction (RSF).

Iron (Fe) exists in the form of iron oxides, organic salt, inorganic or organic composites such as heamiron. The effects of toxic doses associated with Fe studies of animal are categorised by initial depression, respiratory failure, coma or cardiac arrest; convulsion etc ${ }^{37}$. However, $\mathrm{Fe}$ is an essential mineral in every living cell, and it is imperative for the production of hemoglobin, myoglobin and some 
protein cells. Anemia which is one of the commonest nutrient inadequacies in contemporary times is caused by Fe dearth, thereby leaving its victims with weakness, inability to concentrate and susceptibility to infection ${ }^{38}$. Hence, these snails are good sources of Fe to consumers.

\section{Copper Fractionation}

The levels of $\mathrm{Cu}$ in the snail species (Achatina achatina, Limicolaria flammea, Pachymeria aurita and Tympanotous fuscatus are presented on Table 2 and Fig. 2. The data obtained follow the pattern of Pachymeria. Aurita > Tympanotous. Fuscatus $>$ Achatina achatina $>$ Limicolaria flammea with Pachymeria aurita recording the highest value of $8.60 \mathrm{mg} \mathrm{kg}^{-1}$ and Limicolaria flammea recording the lowest value of $1.70 \mathrm{mg} \mathrm{kg}^{-1}$ in the water soluble fraction. For the non-polar or hexane fraction, $\mathrm{Cu}$ levels are in the pattern of Tympanotous fuscatus $>$ Limicolaria flammea > Achatina achatina > Pachymeria aurita. Tympanotous fuscatus recorded the highest value of $8.30 \mathrm{mg} \mathrm{kg}^{-1}$, and Pachymeria aurita recorded the lowest value of $2.80 \mathrm{mg} \mathrm{kg}^{-1}$. In the polar fractions, the results reflected that, Pachymeria aurita > Tympanotous fuscatus > Limicolaria flammea > Achatina achatina. Pachymeria aurita recorded the highest value of $0.93 \mathrm{mg} \mathrm{kg}^{-1}$ and Achatina achatina recorded the lowest value of 0.63 $\mathrm{mg} \mathrm{kg}^{-1}$. While the residual fraction of $\mathrm{Cu}$ follows the pattern of Pachymeria aurita $>$ Achatina achatina $>$ Tympanotous fuscatus > Limicolaria flammea with Pachymeria aurita recording the highest value of $43.38 \mathrm{mg} \mathrm{kg}^{-1}$, and Achatina achatina recording the lowest mean value of $13.53 \mathrm{mg} \mathrm{kg}^{-1}$.

Collectively, the findings showed that, $\mathrm{Cu}$ mean concentrations in the entire snail samples of the residual fraction were higher than the other fractions. This implies that most of the Cu species in these snail samples are stable complexes that can only be released via strong acid digestion. However, reasonable amount of copper found in the nonpolar and water soluble fractions indicate non-polar species (mostly organic) and water soluble species (mostly the cupric, $\mathrm{Cu}^{2+}$ salt which readily dissolve in water to form an aqua complex, $\mathrm{Cu}\left(\mathrm{H}_{2} \mathrm{O}\right)^{2+}{ }_{4}$.) The water molecules can be replaced by variety of organic ligands to form different complexes, and some of these organic complexes are essential to life principally, heamocyania which constitutes the blood pigment found in mollusks ${ }^{39}$. Thus, the concentrations of $\mathrm{Cu}$ in this study in all the fractions were below the standard limits value of $\mathrm{MAFF}^{32}$ and $\mathrm{FAO} / \mathrm{WHO}^{33}$ but higher than the standard limits of IAEA ${ }^{34}$ except in the polar fraction. Copper is an essential trace metal found in living systems, however, prolong exposure (especially higher concentration) has been found to reduce production of antibodies which may lead to brain damage ${ }^{40}$. Other adverse health effects include; anemia, major organ damage such as lungs, liver, kidney and sometime stomach as well as intestinal irritation. The main areas $\mathrm{Cu}$ is commonly found in the human systems are liver, muscle and bone ${ }^{41}$.

\section{Zinc Fractionation}

The fractionation of zinc in the snails species are presented in Table 1 and Fig. 3. The mean concentrations of zinc in the water soluble fraction (WSF) of the snails were; Limicolaria flammea > Achatina achatina > Tympanotous fuscatus > Pachymeria aurita. Limicolaria flammea recorded the highest value of $20.55 \mathrm{mg} \mathrm{kg}^{-1}$, while Pachymeria aurita recorded the lowest value of 3.50 $\mathrm{mg} \mathrm{kg}^{-1}$. Non-polar or hexane fraction (NHF) were; Limicolaria flammea > Tympanotous fuscatus > Pachymeria aurita $>$ Achatina achatina. Limicolaria flammea rank the highest with value of $28.50 \mathrm{mg}$ $\mathrm{kg}^{-1}$, and Achatina achatina ranked the lowest with $26.20 \mathrm{mg} \mathrm{kg}^{-1}(p<0.05)$. The highest mean value of $14.40 \mathrm{mg} \mathrm{kg}^{-1}$ was found in Pachymeria aurita while, Achatina achatina recorded lowest mean value of $13.73 \mathrm{mg} \mathrm{kg}^{-1}$. Finally, in the residual fraction (RSF) of $\mathrm{Zn}$, Limicolaria flammea ranked the highest with value of $63.70 \mathrm{mg} \mathrm{kg}^{-1}$, and Pachymeria aurita ranked the lowest with value of $14.30 \mathrm{mg} \mathrm{kg}^{-1}$.

The concentrations of $\mathrm{Zn}$ in all the snail species in each fraction were evenly distributed except in the WSF and RSF where, Limicolaria flammea were far higher than the other snails. This implies that, $\mathrm{Zn}$ species are readily bioavailable in the snails' environment and are from the same source. Also, the result shows that, the mean value of $\mathrm{Zn}$ in the non-polar (hexane) fractions were higher than other fractions, this indicates more non-polar (organic) species of zinc in these snails. However, the mean concentrations of $\mathrm{Zn}$ in these snails were lower than the recommended standard limits of regulatory bodies presented in Table 1 . These values were higher than the value obtained by Olowoyo, ${ }^{36}$ in periwinkles and tilapia, and the value reported by Chindah et al., ${ }^{20}$ in periwinkles. Zinc plays ubiquitous 
biological roles in the human system. It interfaces with a lot of organic ligands and plays key role in the chemical reaction that occurs in RNA and DNA cells, genetic transfer and genetic expressibility. Also, it regulates the excitableness of the brain ${ }^{42}$. Therefore, these snails are healthy sources of $\mathrm{Zn}$ to the consumer.

Non-carcinogenic Risk Appraisement of $\mathrm{Fe}, \mathrm{Cu}$, Zn in Land and Marine Snails

Non-carcinogenic risk appraisements in this study were conducted using the mean $\mathrm{Fe}, \mathrm{Cu}, \mathrm{Zn}$ concentrations of the various fractions (water soluble, non-polar or hexane, polar or methanol and residual fractions). This frame work is essentially useful in understanding the health hazards associated with individual chemical forms (species) of these metals, rather than total concentration, because metal toxicity, their ecological mobility and bioavailability are related chemical species. For example, Fe (II) is dissolvable under normal physiological states and circulates easily across membranes, while, Fe (III) does not penetrates cells easily and is more susceptible to decomposition in ecological systems ${ }^{43}$. Furthermore, the toxic hazard posed by metals to humans relies on metal(s) concentration in the food in relation to daily consumption over time. The risk assessment models employed in this study were; the estimated dietary intake. EDI, target hazard quotient (THQ) and hazard index proposed by the USEPA ${ }^{27-29}$ and the results obtained are presented in Table 3 and 4.

Table 3: Estimated Dietary, EDI (mg kg-1-bw day-1) of Fe, Cu, Zn in Terrestrial and Aquatic Snail in the Different Fractions

\begin{tabular}{lcccc}
\hline Fractions & Snails & $\mathrm{Fe}$ & $\mathrm{Cu}$ & $\mathrm{Zn}$ \\
\hline Water soluble fraction (WFS) & Achatina achatina & $1.23 \mathrm{E}^{-01}$ & $7.29 \mathrm{E}^{-04}$ & $3.15 \mathrm{E}^{-03}$ \\
& Limicolaria flammea & $8.80 \mathrm{E}^{-02}$ & $7.08 \mathrm{E}^{-04}$ & $8.56 \mathrm{E}^{+03}$ \\
& Pachymeria aurita & $1.40 \mathrm{E}^{-02}$ & $3.58 \mathrm{E}^{-03}$ & $1.46 \mathrm{E}^{-03}$ \\
& Tympanotous fuscatus & $9.00 \mathrm{E}^{+03}$ & $2.25 \mathrm{E}^{-03}$ & $1.73 \mathrm{E}^{-03}$ \\
Non-Polar (Hexane) fraction (NHF) & Achatina achatina & $5.38 \mathrm{E}^{-03}$ & $1.36 \mathrm{E}^{-03}$ & $1.09 \mathrm{E}^{-02}$ \\
& Limicolaria flammea & $1.43 \mathrm{E}^{-02}$ & $2.35 \mathrm{E}^{-03}$ & $1.19 \mathrm{E}^{-02}$ \\
& Pachymeria aurita & $1.23 \mathrm{E}^{-02}$ & $1.17 \mathrm{E}^{-03}$ & $1.10 \mathrm{E}^{-02}$ \\
& Tympanotous fuscatus & $1.45 \mathrm{E}^{-03}$ & $3.46 \mathrm{E}^{-03}$ & $1.16 \mathrm{E}^{-02}$ \\
Polar (methanol) fraction (PMF) & Achatina achatina & $2.59 \mathrm{E}^{-03}$ & $2.63 \mathrm{E}^{-04}$ & $5.72 \mathrm{E}^{-03}$ \\
& Limicolaria flammea & $5.13 \mathrm{E}^{-03}$ & $2.92 \mathrm{E}^{-04}$ & $5.92 \mathrm{E}^{-03}$ \\
& Pachymeria aurita & $4.58 \mathrm{E}^{-03}$ & $4.04 \mathrm{E}^{-04}$ & $6.00 \mathrm{E}^{+03}$ \\
& Tympanotous fuscatus & $4.38 \mathrm{E}^{-03}$ & $3.88 \mathrm{E}^{-04}$ & $5.92 \mathrm{E}^{-03}$ \\
& Achatina achatina & $8.48 \mathrm{E}^{-01}$ & $1.09 \mathrm{E}^{-02}$ & $1.10 \mathrm{E}^{-02}$ \\
& Limicolaria flammea & $2.65 \mathrm{E}^{-01}$ & $5.60 \mathrm{E}^{-03}$ & $2.65 \mathrm{E}^{-02}$ \\
& Pachymeria aurita & $4.49 \mathrm{E}^{-01}$ & $1.81 \mathrm{E}^{-02}$ & $5.96 \mathrm{E}^{-03}$ \\
& Tympanotous fuscatus & $7.36 \mathrm{E}^{-01}$ & $7.02 \mathrm{E}^{-03}$ & $1.06 \mathrm{E}^{-02}$ \\
\hline
\end{tabular}

Table 4: Non-Carcinogenic Risk (THQ\&HI) Appraisals, and the Percentage Hazard Index $(\% \mathrm{HI})$ of $\mathrm{Cu}$, and $\mathrm{Zn}$ in Terrestrial and Aquatic Snail

\begin{tabular}{|c|c|c|c|c|c|c|c|c|}
\hline \multirow[t]{2}{*}{ Fractions } & \multirow[t]{2}{*}{ Snails } & \multicolumn{3}{|c|}{$\mathrm{THQ}$} & \multicolumn{4}{|c|}{$\begin{array}{c}\mathrm{HI}(\Sigma T H Q) \% \text { Contribution of each } \\
\text { metal to } \mathrm{HI}\end{array}$} \\
\hline & & $\mathrm{Fe}$ & $\mathrm{Cu}$ & $\mathrm{Zn}$ & & $\mathrm{Fe}$ & $\mathrm{Cu}$ & $\mathrm{Ze}$ \\
\hline \multirow[t]{4}{*}{ Water soluble fraction (WFS) } & Achatina achatina & $1.75 \mathrm{E}^{-04}$ & $1.82 \mathrm{E}^{-05}$ & $1.05 \mathrm{E}^{-05}$ & $2.04 \mathrm{E}^{-04}$ & 85.91 & 8.94 & 5.15 \\
\hline & Limicolaria flammea & $1.26 \mathrm{E}^{-04}$ & $1.77 \mathrm{E}^{-05}$ & $2.85 \mathrm{E}^{-05}$ & $1.73 \mathrm{E}^{-04}$ & 73.21 & 10.26 & 16.53 \\
\hline & Pachymeria aurita & $1.99 \mathrm{E}^{-05}$ & $8.96 \mathrm{E}^{-05}$ & $4.86 \mathrm{E}^{-05}$ & $1.14 \mathrm{E}^{-04}$ & 17.37 & 78.38 & 4.25 \\
\hline & Tympanotous fuscatus & $1.25 \mathrm{E}^{-05}$ & $5.63 \mathrm{E}^{-05}$ & $5.76 \mathrm{E}^{-06}$ & $7.45 \mathrm{E}^{-04}$ & 16.78 & 75.49 & 7.74 \\
\hline \multirow[t]{4}{*}{ Non-Polar (Hexane) fraction (NHF) } & Achatina achatina & $7.69 \mathrm{E}^{-06}$ & $3.41 \mathrm{E}^{-05}$ & $3.64 \mathrm{E}^{-06}$ & $7.81 \mathrm{E}^{-05}$ & 9.84 & 43.59 & 46.57 \\
\hline & Limicolaria flammea & $2.04 \mathrm{E}^{-05}$ & $5.86 \mathrm{E}^{-05}$ & $3.96 \mathrm{E}^{-05}$ & $1.19 \mathrm{E}^{-05}$ & 17.18 & 49.45 & 33.37 \\
\hline & Pachymeria aurita & $1.76 \mathrm{E}^{-05}$ & $2.92 \mathrm{E}^{-05}$ & $3.67 \mathrm{E}^{-05}$ & $8.35 \mathrm{E}^{-05}$ & 21.11 & 34.95 & 43.94 \\
\hline & Tympanotous fuscatus & $2.07 \mathrm{E}^{-05}$ & $8.65 \mathrm{E}^{-05}$ & $3.86 \mathrm{E}^{-05}$ & $1.46 \mathrm{E}^{-05}$ & 14.63 & 59.31 & 26.49 \\
\hline \multirow[t]{4}{*}{ Polar (methanol) fraction (PMF) } & Achatina achatina & $3.71 \mathrm{E}^{-06}$ & $6.56 \mathrm{E}^{-05}$ & $1.91 \mathrm{E}^{-05}$ & $2.93 \mathrm{E}^{-05}$ & 21.23 & 22.37 & 64.99 \\
\hline & Limicolaria flammea & $7.32 \mathrm{E}^{-06}$ & $7.29 \mathrm{E}^{-05}$ & $1.97 \mathrm{E}^{-05}$ & $3.43 \mathrm{E}^{-05}$ & 17.86 & 21.24 & 57.44 \\
\hline & Pachymeria aurita & $6.55 \mathrm{E}^{-06}$ & $1.01 \mathrm{E}^{-05}$ & $2.00 \mathrm{E}^{-05}$ & 3.67E-05 & 17.53 & 27.57 & 54.57 \\
\hline & Tympanotous fuscatus & $6.25 \mathrm{E}^{-06}$ & $9.69 \mathrm{E}^{-06}$ & $1.97 \mathrm{E}^{-05}$ & $3.57 \mathrm{E}^{-05}$ & - & 27.17 & 55.31 \\
\hline \multirow[t]{4}{*}{ Residual fraction (RSF) } & Achatina achatina & $1.21 \mathrm{E}^{-03}$ & $2.74 \mathrm{E}^{-04}$ & $3.67 \mathrm{E}^{-05}$ & $1.52 \mathrm{E}^{-03}$ & 79.57 & 18.02 & 2.41 \\
\hline & Limicolaria flammea & $3.78 \mathrm{E}^{-04}$ & $1.41 \mathrm{E}^{-04}$ & $8.85 \mathrm{E}^{-05}$ & $6.08 \mathrm{E}^{-04}$ & 62.24 & 23.19 & 14.56 \\
\hline & Pachymeria aurita & $6.42 \mathrm{E}^{-04}$ & $4.52 \mathrm{E}^{-04}$ & $1.99 \mathrm{E}^{-05}$ & $1.11 \mathrm{E}^{-03}$ & 57.65 & 40.57 & 1.78 \\
\hline & Tympanotous fuscatus & $1.05 \mathrm{E}^{-03}$ & $1.76 \mathrm{E}^{-04}$ & $3.52 \mathrm{E}^{-05}$ & $1.26 \mathrm{E}^{-03}$ & 83.31 & 13.9 & 2.79 \\
\hline
\end{tabular}




\section{Estimated Dietary Intake}

The Estimated Dietary Intake (EDI) is an estimated daily intake of a nutriment considered adequate for daily prerequisites of almost $97-98 \%$ healthful persons in a life-time. In this study, a daily intake of $0.025 \mathrm{mg} \mathrm{kg}^{-1}$-bw day-1 was considered safe based on the annual intake of fish and shell fish in Nigeria for meat and fish products which is averaged $9.0 \mathrm{~kg}^{30}$. Nevertheless, the required intakes depend on the concentration of the metal(s) in the snails, the amount of snails consumed daily $(0.025 \mathrm{mg} \mathrm{kg}$ ${ }^{1}$-bw day-1). The body weight of an adult-individual was averaged $60 \mathrm{~kg}$. The results showed that, the estimated daily intake of metals, $\mathrm{Fe}, \mathrm{Cu}, \mathrm{Zn}$ in each fraction of the snails were below the recommended daily allowances set by the Institute of Medicine ${ }^{44}$ and $\mathrm{WHO}^{45}$ at $0.3 \mathrm{mg} \mathrm{kg}^{-1}$-bw day-1 for $\mathrm{Zn}, \mathrm{Cu} ; 0.5$ $\mathrm{mg} \mathrm{kg}^{-1}$-bw day ${ }^{-1}$ and $\mathrm{Fe}$; $10-19 \mathrm{mg} \mathrm{kg}^{-1}$-bw day ${ }^{-1}$ respectively. Therefore, the snails were considered safe for daily intake of $0.025 \mathrm{mg} \mathrm{kg}^{-1}$-bw day-1 at the moment.

\section{Target Hazard Quotient, THQ and Hazard Index, HI}

The THQ of the individual metals ( $\mathrm{Fe}, \mathrm{Cu}$, $\mathrm{Zn}$ ) and the combined hazard indices of all the three metals are shown in Table 4. Results showed that, the $\mathrm{THQ}$ of $\mathrm{Fe}, \mathrm{Cu}, \mathrm{Zn}$ in each fraction of all the snails were less than their oral reference dose. The New York State Department of Health, NYSDOH ${ }^{46}$, reported that, the risk of a contaminant becomes minimal if the ratio of the THQ to its RfD is equivalent or > RfD values of the contaminant. Also, the aggregated effects of the metals under investigation were lower than maximum tolerable limits of I $(\mathrm{HI}>$ I) in each snails' fraction. This indicates that, these metals (Fe, $\mathrm{Cu}, \mathrm{Zn}$ ) will not pose non-carcinogenic risk via consumption of these snail species. However, studies had revealed that a given matrix may contain more than two or three pollutant or toxicant and often suffer combined or interactive effects ${ }^{47}$. Therefore, considering the combined interactive effects of other pollutants and the bio-accumulative innate characteristics of metals, moderate consumption of these snails is recommended.

\section{CONCLUSION}

This study provided data on fractionation of $\mathrm{Fe}, \mathrm{Cu}, \mathrm{Zn}$ in different snail species obtained from Bayelsa State Nigeria. The results showed variability of the metals in each fraction of the snails. Fe accumulated higher than $\mathrm{Cu}, \mathrm{Zn}$ in all the snail species and Fe levels were highest in the residual fraction contributing over $70 \%$ to the H.I. values especially in Achatina achatina and Tympanotous fuscatus. Again, the Fe levels in these snails were more than the maximum recommended values of M.A.F.F., F.A.O./W.H.O., I.A.E.A. while, $\mathrm{Zn}$ and $\mathrm{Cu}$ levels were below the limits set by these regulatory bodies. The present study also revealed that, a daily consumption of $0.025 \mathrm{mg} \mathrm{kg}^{-1}$-bw/day ${ }^{-1}$ of $\mathrm{Fe}, \mathrm{Cu}, \mathrm{Zn}$ in these snail species will not pose non carcinogenic risk at the moment. However, more research should be carried out on other pollutants such as persistent organic pollutant (POPS) of health concern (e.g chlorinated pesticides, dichlorodiphenyltrichloroethane, DDT, polychlorinated biphenyl (PCBs) etc.

\section{ACKNOWLEDGEMENT}

The authors specially thank the Laboratory Technologists and the entire management of the Central Research Laboratory, Pure and Industrial Chemistry Department, University of Port Harcourt, Choba, Rivers State, Nigeria for the assistance rendered during the experimental work and especially the used of their facilities.

\section{Conflict of interest}

No conflict of interest

\section{REFERENCES}

1. Templeton, D.M.: Ariese, F.: Cornelus, R.: Danielson, L.G. Muntabu. IUPA Guidelines for terms Related to Chemical Speciation and Fraction of Elements; Definitions, Structural Aspects and Methodological Approaches. Pure Appl. Chem., 2002, 72(8), 1453-1470.

2. Okoro, H.K.; Fatoki, O.S.; Adekola, F.A.; Ximba, B.J.; Snyman R.G. A Review of Sequential
Extraction Procedures for Heavy Metal Speciation in Soil and Sediments., 2012, 1, 181 joil 10, 4, 7,//science report. 181.

3. Krauss, P.; Blessing, R.; Korherr, U. Heavy Metal I. Compost from Municipal Refuse Strategies to reduce their Content to Acceptable Levels: In Debertold: et al (Eds). Compost, Production Quality and Use. Elsevier. Applied Science Publisher London., 1987, 254-265. 
4. Margui, E.; Salvado, V.; Queralt I.; Hidalgo, M. Comparison of Three Stage Sequential Extraction Toxicity Characteristic Leaching Tests to Evaluate Metal Mobility in Mining Wastes. Anal Chim Acta., 2004, 524, 154-159.

5. Tessier, A. Compbell, P.G.C., Bisson, M. Sequential Extraction Procedure for Speciation Extraction of Particulate Trace Metals. Anal Chem., 1979, 54, 844-851.

6. Erika-Andrea, F.; Michael, P.; Corodo S.E. Use of Sequential Extraction to Assess Metal Fractionation in Soils from Bozanta Mare, Romania. Acta Universitis Cibrinieasis Seria F. Chemia., 2005, 8, 5-12.

7. Petruzelli, G.; Seymura, I.; Lubrano I.; Pezzarosa, B. Chemical Speciation of Heavy Metals. Environmental Technology Letter., 1989, 10, 510-526.

8. Svete P.; Milacie, R.; Philar B. Comparison of Original and Modified BCR Sequential Extraction Procedures for the Fractionation of Copper, Iron, Lead, Manganese and Zinc in Soil and Sediments. Anal Chim Acta., 2001, 478, 111-118.

9. MOSSOP, K.F.; Davidson, C. M. Partitioning of $\mathrm{Zn}, \mathrm{Pb}$ and $\mathrm{Cd}$ in River Sediments from Lead and Zinc Mining area using the BCR three step Sequential Extraction Procedure. J. Environ. Monit., 2003, 3, 586-590.

10. Alvarez, E. A.; Mochon, M.C.; Jimene, Z.; Scanchez, J.C.; Ternero R.M. Heavy Metal Extractible Forms in Sludge from Waste Water Treatment Plants. Chemosphere., 2002, 47, 765-775.

11. Yuan, X.; Huag, H.; Zeng, G.; Li, H.; Wang, J.; Zhon, C.; Zhu, H.; Pei, X.; Liu, Z. Total Concentrations and Chemical Speciation of Heavy Metals in Liquefaction Residues of Sewage Sludge. Bioresources Technology., 2011, 102, 4104-4110.

12. Li, L.; Xu, Z.; Wu, J.; Tian, G. Bioaccumulation of Heavy Metals in the Earthworm Eisenia Fetida in Relation to Bioavailable Metal Concentrations in Pig Manure. Bioresources Technology., 2010, 101, 840-3436.

13. Ramirez, M.; Massolo, S.; Frache, R.; Juan, A.; Correa, M. Metal Speciation and Environmental Impact on Sandy Beaches due to Ei Salvador Copper Mine, Chile Marine Pollution Bulletin., 2005, 50, 62-72.

14. Fagburo, O.; Oso, J.A.; Edward, J.B.; Ogunleye, R.F. Nutritional Status of Four Species of Giant Land Snail in Nigeria. Journal of Zheijiang University, Science B., 2006, 7, 9.
15. Ademolu, K.O.; Idowu, A.B.; Mafiana, Osinowo, O.A. Performance, Proximate and Mineral Analysis of African Giant Land Snail (Archachatina marginata). Fed Different Nitrogen Sources Tropical Veterinarian., 2007, 25(4), 124-131.

16. Funmilayo, S.M. Preliminary Investigation of the Growth Performance of Giant Land Snail Archachatina marginata) Fed with Selected Wastes. African Journal of Agricultural Research., 2008, 3(9), 647-649.

17. Wosu, I.O. Commercial Snail Farming in West Africa: A guide AP Express Publishers Ltd, Nsukka., 2003.

18. Dambo, W.B. Tolerance of the Periwinkle P. aurita and T. fuscatus to refined oils. Environ Pollutions., 1993, 79(3), 293-296.

19. Ejidike. B.N. Snail Rearing Practices in Southern Nigeria. Nigerian Society of Animal Production, $27^{\text {th }}$ Annual Conference. March 17-21, 2001, Akure, Nigeria, 2002, 307-308.

20. Chindah, A.C.; Braid, S.A.; Amakiri, J.; Chikwendu, S.O.N. Heavy Metal Concentrations in Sediment and Periwinkles. Tympanotonus fuscatus in Different Ecological Zones of Bonny River System, Niger Delta, Nigeria. The Open Environmental Pollution and Toxicology Journal., 2009, 1, 93-106.

21. Otitoloju, A.A.; Ajikobi, D.O.; Egonmwan, R.I. Histopathology and Bioaccumulation of Heavy Metals (Cu and $\mathrm{Pb}$ ) in the Giant Land Snail, Archachatina marginata (Swainson). The Open Environmental Pollution and Toxicological Journal., 2009, 1, 79-88.

22. Odu, N.N.; Igwiloh, NJPN, Okonko I.O.; Njoku H.O. Heavy Metal Levels of Some Edible Shell Fish from Kararugbari Creek in Rivers State, Nigeria. Journal of American Science., 2011, 7(9), 802-809.

23. Markmanuel, D.P.; Horsfall, Jnr. Evaluation of Carcinogenic and Non-carcinogenic Risk of Cadmium and Nickel in Land Snails ( $A$. achatina and L. flammea) andMarine Snails ( $P$. aurita and $T$. fuscatus) commonly consumed in Nigeria. Acta Chim Pharm Indica., 2016, 6, 123-134.

24. Akoto, O.; Bismark, F.; Darko, G.; Adei E. Concentration and Health Risk Assessments of Heavy Metals in Fish from the Tosu Lagoon. Int. J. Environ. Res., 2000, 8(2), 403-410.

25. Kumar, B.; Mukherjee D.P. Assessment of Human Health Risk for Arsenic, Copper, Nickel, Mercury and Zinc in Fish Collected from Tropical Wetlands in India, Adv. Life Sci. Technol., 2011, 2, 13-24. 
26. Osakwe.; J.O. Adowei, P.; Horsfall, M.J. Metal Body Burden and Evaluation of Human Health Risk in Africa Catfish (Clarias Gariepinus) from Imo River, Nigeria. Acta Chim Parm Indica., 2014, 4(2), 78-89.

27. USEPA. Risk Assessment Guidance for Superfund; Vol. III Part A. Process for Conducting Probalistic Risk Assessment, 2001, EPA 540-R-02-002. OSWER 92857-45 P132002 1963302.

28. USEPA. USEPA Regional Screening Level (RSL) Summary Table. November., 2011.

29. USEPA. Reference Dose (RfD): Description and Use in Health Risk Assessment, Background Document IA, Integrated Risk Information System (IRIS). United States Environmental Protection Agency, Washington DC., 2016.

30. FAO. Current Worldwide Annual Meat Consumption Per capita, Livestock and Fish Primary Equivalent. Food and Agriculture Organization of the United Nation, 2013. Retrieved from https://en.wikipedia.org/w/ indea. Php 7 title: List of Countries by Meat Consumption and Oldid $=902683299$.

31. Markmanuel, D.P.; Young, E.; Godwin, J. The effects of Processing on Heavy Metals Concentration and Health Risk Assessment in African Palm Weevil (Rhynchophorus phoenicis) Larvae. Toxi App Phar Insig., 2019, 2(1), 1-5.

32. MAFF. Monitoring and Surveillance of Nonradioactive Contaminants in the Aquatic Environment and Activities Regulating the Disposal of Waste at Sea. Aquatic Environment Monitoring Report., 1993, 1995, 44, Directorate of Fisheries Research, Lowstotr.

33. FAO/WHO. FAO/World Health Organization Codex Alimentarius. General Standards for Contaminants and toxins in food. Schedule Maximum and Guideline Levels for Contaminants and Toxin in Food. Reference CX/FAC 02116. Joint FAO/WHO Food Standard Programme. Codex Committee, Rolterdam, the Netherlands., 2002.

34. Wyse,E.J.; Azemard, S.; Mora S.J. Report on the Worldwide Intercomparison of Exercise for the Determination of Trace Elements and Methylmercury in Fish Homogenate., 2003, IAEA407 IAEA > AL444 (IAEA MONACO Pp 1-4).

35. Ibe, F.C.; Njoku, V.O.; Johnson, C. Study of the Level of Heavy Metals in Water and Fish Samples from Imo River at Ihitte/Uboma, Imo State, Nigeria, J. Chem Soc. Nigeria., 2015, 40(1), 102-106.
36. Olowoyo, D.N. Heavy Metal Concentration in Periwinkle (Lithoria lithorea) and Tilapia (Tilapia zilli) from the Coastal Water of Warri, Nigeria. American Journal of Food Nutrition., 2011, 1(3), 102-108.

37. Reena, S.; Neetu, G.; Anurage, M., Gupta, R. Heavy Metals and Living Systems. An Overview India Journal of Pharmacology., 2011, 43(3), 246-253.

38. Spear, J.W. Micro Nutrients and Immune Function in Cattle. Processing of the Nutrition Society., 2000, 59, 587-594.

39. Dojlido, J.R.; Best, G.A. Chemistry of Water and Water Pollution. Ellis Horwood Limited, Herts., 1993, 65-69, 84-91, 108-114, 201-205.

40. Malcon S.; Howard, N.; Harry, D. Chemistry Principle and Concept. Prentice-Hall Inc. Englewood Cliffs, N.J., 1996, 260-263.

41. Johnson and Larry, "Copper" Merck Manuel Home Health Handbook. Mercksharp and Dohme Crop. A Subsidiary of Merck and Co., 2008, 04-07.

42. Hambidge, K. M., Krebs, N.F. "Zinc Deficiency: A Special Challenge". J.Nut., 2007, 137(4), 1101-1105.

43. Schenider, W.; and Schwyn, B. In the hydrolysis of Iron in Synthetic, Biological and Aquatic Media, in Aquatic Surface Chemistry: Chemical Processes at the Particle-Water Interface, W. Stumm (Ed.)., 1987, 167-196.

44. Institute of Medicine Dietary Reference Intakes: Applications in Dietary Planning. Subcommittee on Interpretation and Uses of Dietary Reference Intakes and the Standing Committee on the Scientific Evaluation of Dietary Intakes. Washington, DC. The National Academics Press., 2003, 248.

45. WHO. Evaluations of the Joint FAO/WHO Expert Committee on Food Additives, 2017,http:// apps,who.int/food-additives-contaminantsjecta-database/search.aspx?Fcc=2.

46. NYSDOH. New York State Department of Health. Hopewell Precision Area Contamination: Appendix C-NYS DOH. Procedure for Evaluating Potential Health Risks for Contaminants of Concern., 2007.

47. Li, J., Huang. Z. Y., Hu, Y., Yang, H. Potential Risk Assessment of Heavy Metals by Consuming Shellfish Collected from Xiamen, China. Environ. Sci. Pollut. Res., 2018, 20, 2937-2947. 